\title{
The Correlation between Academic Ability and Scientific Skills in The Selection of Outstanding School Library Staff
}

\section{Rismita $^{1^{*}}$}

${ }^{1}$ Educational Administration, Universitas Muhammadiyah PROF. DR. HAMKA (UHAMKA), Jakarta, Indonesia

A R T I C L E I N F O

Article history:

Received 18 August 2020

Received in revised

Form 06 September

2020

Accepted 18 October

2020

Available online 01

November 2020

Keywords:

Academic ability

assessment; scientific

skills; school library.

\begin{abstract}
A B S T R A C T
Selection of outstanding school librarians due to increased information literacy has an impact on student achievement but in the implementation of the scientific skills assessment some participants do not understand the testing standards and have difficulty interpreting the principles of the measured test. The research objective was to examine the relationship between academic ability and scientific skills. Respondents amounted to 35 school library staff using purposive sampling. Validity and reliability were analyzed from the highest assessment of each level of education based on the top three rankings using the Spearman rank correlation. The results showed a significant relationship between academic ability and scientific skills of outstanding school library staff with $\rho$ value $=0.784$ and $\rho$ table at $\alpha=5 \%$ was 0.683 . That is, high academic ability results in an increase in the scientific skills of outstanding school librarians. This research has implications for maintaining the professional balance of library personnel who are integrated with technological developments that have a positive impact on schools in dealing with the transition to electronicbased systems.
\end{abstract}

\section{Introduction}

The support of library personnel in schools has an important role in school management and makes a valuable contribution to children's learning (Merga, 2019), and library services are essential services needed in the school system (Suleiman et al., 2018), and are needed to implement contents of the school curriculum (Sunmade \& Anu, 2019). Schools have a responsibility to maintain, ensure the welfare and improve the education of students (Hayden et al., 2019), because education is a gateway to future escalation that has an impact on the social, physical and economic environment in life (Jeyaraj, 2017). The importance of library professionals such as those developing in developed countries (United States, United Kingdom and others) who recognize the need for information literacy that has an impact on student success academically and is an integral part of the school curriculum so that the learning process becomes easy and becomes a strong basis for future life of students (Hanchinal \& Hanchinal, 2018).

In improving the quality of education services through library staff, competence is needed. Each competency contributes significantly to the selection of outstanding librarians to increase individual and organizational library assets through performance assessment of librarians and increases the ability to dynamically apply skills to change which have an impact on the increasing value of library staff to school organizations (Metz, 2011), and competence is very important to increase mastery of skills, knowledge and develop self-confidence in problem solving (Makunja, 2016).

Competence is needed to maintain the professional balance of library personnel and develop library progress. The competence of librarians in achieving achievement must show meaningfulness in work and understanding of goals that include five job characteristics, namely skill variation, task identity, task significance, autonomy, and job feedback (Martin, 2020), the professionalism of librarians has the ability to organize and maintain. information by tracking information systematically, and realizing the importance of presenting as much information as possible (Mackall, 2004), and individual performance which is included in the indicator of academic ability reflects commitment in work (Tella \& Ibinaiye, 2020).

Related research states that evaluating library performance is measured by five categories, namely (a) service quality, (b) facilities, equipment, and the physical environment, (c) resources, (d) 
electronic resources, and (e) new services. which is implemented by the library. The results showed that 71.8 percent of respondents preferred to use printed books compared to 28.2 percent who preferred to use electronic books. Based on the results of this study, it shows that this is related to the performance problem of library employees in serving respondents to the library by emphasizing (1) increasing collection resources, (2) renovating the library for user space, (3) developing services that equip users for interaction in providing information (Babalhavaeji et al., 2009). Other research also explains that the application of a framework, reflection and scientific skills of librarians in communication, insight into librarian identity, the role of values and professional development have an influence on library practice (Delaney et al., 2020).

The description of Babalhavaeji and Delaney's research results above, became a factor for researchers to write this article regarding the effect of academic performance appraisal on the selection of outstanding school library staff, because academic achievement has many benefits in the modern education system (Bhat, 2016). The selection of outstanding school librarians is a manifestation of the government's program to increase achievement motivation for school library staff, as stated in the guidelines for the assessment of library staff with the theme "Achieving Library Staff Who Can Support Progressive Education". In the selection of outstanding library staff held by the regional education service clan of West Jakarta administration city, it is based on the competencies that have been established in the regulations of the ministry of education and culture, namely regulations of the ministry of education and culture number 25 of 2008 which states that library staff must have six competencies, namely managerial competence, competence information management, educational competence, personality competence, social competence, and professional development competence.

The regional education service sub-district II of the West Jakarta administration city held a competition for selection of outstanding librarians aimed at fulfilling the desire for better education on social and technical issues dealing with the public (Morgan et al., 2018), and gaining knowledge through experience and interaction with the environment continuing through life as well as the development of knowledge and skills in academic situations (Bahar \& Maker, 2020), and influencing self-perception of emotional abilities and skills, personality characteristics and behavioral dispositions that affect the ability to cope successfully with environmental demands and pressures (Amalu, 2018).

The ATPUSI institution (Association of Indonesian School Libraries) also explained that the purpose of this organization was to increase the professionalism of school library staff; developing library science, documentation, and information; devote and practice the manpower and expertise of school library personnel for the nation and the Republic of Indonesia. Another phenomenon in holding this electoral selection is as a benchmark to observe directly the performance standard for determining feedback. If the performance is above the standard, then the standard becomes the basis for positive feedback, and if on the contrary if the performance is below the standard then corrective feedback is used.

Academic assessment of library staff in the selection of achievement is measured through academic ability as a variable $\mathrm{Xi}$, which includes the ability to take computer assisted tests and compilation of portfolios. Academic ability is an ability that is influenced by knowledge (Ika Noviyanti et al., 2019), and the ability to construct ideas logically (Karbalaei, 2012), and is related to the effects of intelligence (Karagöl \& Bekmezci, 2015). The purpose of the academic library is to support the school's academic programs that help improve the intellectual abilities of participants (Raghu, 2017). The Yi variable is scientific skills, which includes creative thinking skills as an important component that must be mastered (Maharani et al., 2020), these skills can certainly help in dealing with problems practically and effectively (Mahanal et al., 2019). Scientific skills are an understanding in carrying out tasks as library staff who are tested through interviews and making scientific papers, which are used to test the ability level of librarians as the biggest challenge for libraries to enable school organizations to continue to work and adapt to a changing and increasingly complex environment. . So that through this selection process, it will help school organizations to advance about library arrangement by implementing a service model in accordance with developments that occur. The reason the researcher uses the variable academic ability and scientific skills in this study is based on a book entitled "Human Resource Development", that the employee performance instruments differ in the type and level of their position in determining achievement, for example, in a non-management position it requires little or no change. year to year, on the other hand, requires an assessment of its competence. Rowley \& Jackson's observations show that 60 percent of the overall ranking is based on objective results, while the remaining 40 percent is based on competency rankings (Rowley \& Jackson, 2011).

This research is important because thinking skills and scientific skills are processes that are relevant to creativity, task motivation, and are the foundations for performance which fall into three components, namely: (a) innate cognitive abilities, (b) innate perceptual and motor skills, and (c) formal and informal education. Characteristics of intellectual abilities and creative personality characteristics are 
reflected in processes relevant to creativity (Zimmerman et al., 2020), as well as a critical component in the selection of outstanding librarians is to face the explosion of information, development and application of Information and Communication Technology (ICT). and growing trends in library and information services that promote continuing education. Facing the dynamics of change requires a new set of skills and knowledge to overcome the challenges and problems of professional life for library workers (Rafiq et al., 2017).

\section{Methods}

The population that is the object of this research is all the school library employees who are in the area of the education office area II, West Jakarta. The number of respondents used was 35 people. The sample was taken by using non probability sampling method with purposive sampling technique. Sampling was carried out by non-probability sampling because each member did not have the same opportunity to be selected. Meanwhile, purposive sampling is intended because the sample used in the study was chosen deliberately based on the criteria set by the researcher. Instrument testing with competency tests or tests and open-ended questions through interviews and presentations were used as measurements in determining the selection of outstanding librarians. To measure rankings in identifying academic performance assessments on the selection of outstanding school librarians, the quantitative research method of Rank Spearman correlation is used, which tests the associative significance of the academic ability variable (Xi) and scientific skills (Yi) with the hypothesis testing criteria, if $\mathrm{HO}$ is rejected if $\rho$ value $>$ from $\rho$ table, and H0 is accepted if $\rho$ value $\leq \rho$ table with significance test $(\alpha) 5 \%$.

\section{Result and Discussion}

\section{Result}

The results of the study using percentage data analysis for the respondent characteristics section and rank Spearman analysis can be explained that for the results of the characteristics of the respondents can be seen in Table 1.

Table 1. Description of Respondent Characteristics

\begin{tabular}{cccc}
\hline No, & Place of Duty & Academic Ability & Scientific Skills \\
\hline 1. & SMKN 45 & $\mathbf{5 0 , 4 3}$ & $\mathbf{9 1 , 0 0}$ \\
2. & SMKN 13 & $\mathbf{3 7 , 4 2}$ & $\mathbf{8 4 , 8 3}$ \\
3. & SMKN 60 & $\mathbf{3 1 , 8 6}$ & $\mathbf{5 6 , 5 0}$ \\
4. & SMK Jakarta III & 0,00 & 42,66 \\
5. & SMKN 17 & $\mathbf{4 7 , 5 2}$ & 0,00 \\
6. & SMAN 112 & $\mathbf{4 6 , 4 3}$ & $\mathbf{7 6 , 1 6}$ \\
7. & SMAN 57 & $\mathbf{3 4 , 0 0}$ & $\mathbf{7 5 , 8 3}$ \\
8. & SMAN 16 & 33,80 & $\mathbf{5 6 , 5 8}$ \\
9. & SMAN 85 & 30,00 & 55,00 \\
10. & SMAnas Bangsa & 25,50 & 0,00 \\
11. & SMAN 65 & 19,00 & 0,00 \\
12. & SMAN 101 & 4,50 & 0,00 \\
13. & SMAN 78 & 0,00 & 0,00 \\
14. & SMA Pelita II & $\mathbf{4 1 , 1 5}$ & 0,00 \\
15. & SMPN 111 & $\mathbf{3 9 , 8 8}$ & $\mathbf{8 1 , 6 6}$ \\
16. & SMPN 207 & $\mathbf{7 2 , 0 1}$ & $\mathbf{6 4 , 0 0}$ \\
17. & SMPN 271 & 34,50 & 62,00 \\
18. & SMPN 134 & 35,00 & 0,00 \\
19. & SMPN 130 & 34,14 & 0,00 \\
20. & SMPN 142 & 32,80 & 0,00 \\
21. & SMPN 197 & 29,50 & 0,00 \\
22. & SMPN 69 & 29,07 & 0,00 \\
23. & SMPN 215 & 29,00 & 0,00 \\
24. & SMPN 191 & 29,00 & 0,00 \\
25. & SMPN 274 & 28,00 & 0,00 \\
26. & SMPN 82 & &
\end{tabular}




\begin{tabular}{lccc}
\hline No, & Place of Duty & Academic Ability & Scientific Skills \\
\hline 27. & SMPN 105 & 27,50 & 0,00 \\
28. & SMPN 101 & 27,50 & 0,00 \\
29. & SMPN 75 & 23,00 & 0,00 \\
30. & SMPN 88 & 20,50 & 0,00 \\
31. & SMPN 220 & 19,00 & 0,00 \\
32. & SMPN 127 & 18,50 & 0,00 \\
33. & SMPN 286 & 15,50 & 0,00 \\
34. & SMPN 219 & 14,00 & 0,00 \\
35. & SMPN 61 & 0,00 & 0,00 \\
\hline
\end{tabular}

The test results of academic ability and scientific skills in table 1 above are sorted according to the ordinal rankings of the tests followed by library staff, and the first to third ranks are taken for the Spearman Rank correlation test. The highest value of the academic ability variable (Xi) is 50.43 and the lowest score is 31.86 . While the scientific skill variable (Yi), the highest value obtained is 84.83 and the lowest score is 56.50 . In the table, it can be seen that there is a value of 0.00 which describes the participants' lack of understanding of the test standards and the difficulty of interpreting the test principles that were actually measured (Kuramoto \& Koizumi, 2018).

Based on the results of the research described in table 1 above, to test the relationship between variables to the Spearman Rank analysis, 9 (nine) respondents were included in the criteria for determining outstanding library staff who were taken from the first to the third rank in each school where they served. library staff, because based on the rules set by the West Jakarta Region II Education Office in determining the selection of outstanding library staff. Then the ranks 1 to 3 are sorted from the education level of SMP, SMA and SMK. Statistical calculations to test the relationship are listed in Table 2.

Table 2. Statistical calculations based on rank

\begin{tabular}{|c|c|c|c|c|c|c|}
\hline No & Academic Ability (Xi) & Scientific Skills (Yi) & $\mathrm{X}$ & $\mathrm{Y}$ & $\mathrm{d}$ & $\mathrm{d}^{2}$ \\
\hline 1 & 41,15 & 81,66 & 6 & 7 & -1 & 1 \\
\hline 2 & 39,88 & 72,00 & 5 & 4 & 1 & 1 \\
\hline 3 & 35,21 & 64,00 & 3 & 3 & 0 & 0 \\
\hline 4 & 47,52 & 76,16 & 8 & 6 & 2 & 4 \\
\hline 5 & 46,43 & 75,83 & 7 & 5 & 2 & 4 \\
\hline 6 & 34,00 & 56,58 & 2 & 2 & 0 & 0 \\
\hline 7 & 50,43 & 91,00 & 9 & 9 & 0 & 0 \\
\hline 8 & 37,42 & 84,83 & 4 & 8 & -4 & 16 \\
\hline \multirow[t]{2}{*}{9} & 31,86 & 56,50 & 1 & 1 & 0 & 0 \\
\hline & Total & & & & & 26 \\
\hline
\end{tabular}

Source: primary data, processed by researchers

Data analysis to test the correlation of the significance of the associative hypothesis in the form of ordinal between the variables of academic ability and scientific skills using the Spearman Rank correlation analysis, whose calculations are described in Table 2 above.

The Spearman Rank Correlation Formula $(\rho=$ rho):

$\rho=1-\frac{6 \Omega d^{2}}{n\left(n^{2}-1\right)}$

$\rho=$ Spearman Rank correlation value

$\mathrm{d}^{2}=$ difference between two observations

$\mathrm{N}=$ total observations

\section{Discussion}

The results of the calculation of the Rank Spearman analysis (the value of $\rho$ calculated) is 0.784 . To determine whether there is a relationship between variables, the calculated value of $\rho$ is 0.784 compared to the value of $\rho$ table at the significance level $\alpha(0.05)$ obtained from the table for the value of $\rho$ (RHO), the Spearman Rank correlation is 0.683.

In this case the null hypothesis (Ho) is: there is no relationship between the variable academic ability (Xi) and scientific skills (Yi). While the alternative hypothesis ( $\mathrm{Ha}$ ) is: there is a positive and 
significant relationship between the variable academic ability (Xi) and scientific skills (Yi). The results obtained concluded that $\rho$ value $(0.784)>\rho$ table $(0.683)$, thus the null hypothesis (Ho) is rejected and the alternative hypothesis (Ha) is accepted. The results of this hypothesis analysis show that there is a significant relationship between academic ability and scientific skills of school library staff, which results in school librarians who are in the area of the West Jakarta District II Education Office to have quality in their duties as librarians so that the quality of service is high, by harmonizing through a library vision (Oxley, 2018). Related research support says that increasing academic performance affects the use of school libraries for students (Solomon, 2018), and individual interpersonal demands on job professionals (Rismita et al., 2020).

In achieving good standards relating to the achievement of one's performance, because performance is a ranking of achievement and the extent to which the task is completed. In this case, of course, library staff are required to be able to achieve good performance, as expressed by experts, namely to measure academic performance (ability), there must be a parameter to assess the extent to which a person is progressing academically. Librarians who are high-performing in achievement are measured based on management effectiveness, development of staffing and professional competence of academic staff (Victor, 2017), and placement of qualified personnel into teaching services will help standardize the school system (Chiedozie, 2018).

Based on theoretical understanding of empowerment and pedagogical education practices critically in theory says that the more literature that refers to conditions and characteristics, the more empowerment will be developed (Kirk et al., 2017). Other supporting research reveals that skill-based competencies are important for lifelong learning (Mosha, 2012), and the ability to use science process skills is important for individual life in society. Science Process Skills have the ability to make a major contribution to the improvement of society (Aydogdu, 2017), and are an important indicator of problemsolving abilities (Zeitoun \& Hajo, 2015).

Theoretically, subsequent research findings reveal that knowledge that can improve academic ability explains human development in learning and provides opportunities for educational practice to be more effective (Darling-Hammond et al., 2020). Meanwhile, scientific skills as a reflection of the cognitive skills of the library staff can influence thinking skills to excel in work and planning for the future by utilizing the advantages of the executive function, namely the ability to disseminate information in working memory as a whole (Blair, 2016). The function of the school library is supported by research that explains the school library helps students' habits to improve reading skills (Dzandza, 2017), and is a role that supports the school curriculum through material access and information literacy programs (Diyaolu, 2019), because libraries play an important role in improving the learning landscape in schools.

\section{Conclusion}

Based on the results of testing and discussion, the research findings indicate that the assessment of academic ability is significantly related to the scientific skills of outstanding school librarians. This means that high academic ability results in improving the scientific skills of outstanding school librarians. Efforts that need to be done are the need to develop academic skills based on integrated knowledge with technological developments that have a positive impact on education or schools, because changes in Information and Communication Technology (ICT) are increasingly changing the landscape of libraries and are a challenge to the traditional role of professional personnel. libraries, improving the quality of scientific skills of librarians in dealing with the switch to electronic-based systems to apply STEM (Science, Technology, Engineering, and Mathematics).

\section{References}

Amalu, M. N. (2018). Emotional Intelligence as Predictor of Academic Performance among Secondary School Students in Makurdi Metropolis of Benue State. International Journal of Scientific Research in Education, Vol. 11(1), 63-70.

Aydogdu, B. (2017). A Study on Basic Process Skills of Turkish Primary School Students. Eurasian Journal of Educational Research, 17, 51-69. https://doi.org/10.14689/ejer.2017.67.4

Babalhavaeji, F., Isfandyari-Moghaddam, A., Aqili, S. V., \& Shakooii, A. (2009). Quality assessment of academic library performance: The case of an Iranian academic library. Malaysian Journal of Library \& Information Science, Vol.14, no.2, 51-81. 
Bahar, A. K., \& Maker, C. J. (2020). Culturally Responsive Assessments of Mathematical Skills and Abilities: Development, Field Testing, and Implementation. Journal of Advanced Academics, 31(3), 211-233. https://doi.org/10.1177/1932202X20906130

Bhat, M. A. (2016). The Predictive Power of Reasoning Ability on Academic Achievement. International Journal of Learning, Teaching and Educational Research, Vol. 15, No. 1, 10.

Blair, C. (2016). Developmental Science and Executive Function. Current Directions in Psychological Science, 25(1), 3-7. https://doi.org/10.1177/0963721415622634

Chiedozie, O. L. (2018). Relationship between Staff Human Resource Management and Academic Performance of Accounting Students in Secondary Schools in Akoko South-West, Ondo State. 04(08), 11.

Darling-Hammond, L., Flook, L., Cook-Harvey, C., Barron, B., \& Osher, D. (2020). Implications for educational practice of the science of learning and development. Applied Developmental Science, 24(2), 97-140. https://doi.org/10.1080/10888691.2018.1537791

Delaney, M., Cleary, A., Cohen, P., \& Devlin, B. (2020). Library Staff Learning to Support Learners Learning: Reflections from a Two-Year Professional Development Project. New Review of Academic Librarianship, 26(1), 56-78. https://doi.org/10.1080/13614533.2019.1681483

Diyaolu, O. (2019). Appraisal of Library Services in Selected Primary Schools under the State Universal Basic Education Board (SUBEB) Oyo State, Nigeria. University of Nebraska - Lincoln, 20.

Dzandza, P. E. (2017). The preparedness of Ghana's School Libraries Towards the achievements of the SDGS: A study of Senior High Schools in the AKWAPIM North district. Ghana Library Journal, 27, 19.

Hanchinal, V. B., \& Hanchinal, V. V. (2018). Information Literacy in Indian Schools: Trends and Developments. International Journal of Knowledge Content Development \& Technology, 8(4), 7-18. https://doi.org/10.5865/IJKCT.2018.8.4.007

Hayden, N. K., McCaffrey, M., Fraser-Lim, C., \& Hastings, R. P. (2019). Supporting siblings of children with a special educational need or disability: An evaluation of Sibs Talk, a one-to-one intervention delivered by staff in mainstream schools. Support for Learning, 34(4), 404-420. https://doi.org/10.1111/1467-9604.12275

Ika Noviyanti, N., Rosyadah Mukti, W., Dahlia Yuliskurniawati, I., Mahanal, S., \& Zubaidah, S. (2019). Students' Scientific Argumentation Skills Based on Differences in Academic Ability. Journal of Physics: Conference Series, 1241, 012034. https://doi.org/10.1088/1742-6596/1241/1/012034

Jeyaraj, W. J. (2017). Job Satisfaction Level of Teacher Librarians of National Schools in the Batticaloa District of Sri Lanka. Journal of Research in Humanities and Social Science, 5(6), 8.

Karagöl, İ., \& Bekmezci, S. (2015). Investigating Academic Achievements and Critical Thinking Dispositions of Teacher Candidates. Journal of Education and Training Studies, 3(4), 86-92. https://doi.org/10.11114/jets.v3i4.834

Karbalaei, A. (2012). Critical thinking and academic achievement. Universidad de Antioquia Colombia, $17(2), 9$.

Kirk, C. M., Lewis, R. K., Brown, K., Karibo, B., Scott, A., \& Park, E. (2017). The Empowering Schools Project: Identifying the Classroom and School Characteristics That Lead to Student Empowerment. Youth \& Society, 49(6), 827-847. https://doi.org/10.1177/0044118X14566118

Kuramoto, N., \& Koizumi, R. (2018). Current issues in large-scale educational assessment in Japan: Focus on national assessment of academic ability and university entrance examinations. Assessment in Education: Principles, Policy \& Practice, 25(4), 415-433. https: //doi.org/10.1080/0969594X.2016.1225667

Mackall, J. (Ed.). (2004). Research and information management (2nd ed). Ferguson Publishing.

Mahanal, S., Zubaidah, S., Sumiati, I. D., Sari, T. M., Graduate School of Universitas Negeri Malang, Indonesia, \& Ismirawati, N. (2019). RICOSRE: A Learning Model to Develop Critical Thinking Skills for Students with Different Academic Abilities. International Journal of Instruction, 12(2), 417434. https://doi.org/10.29333/iji.2019.12227a

Maharani, N., Suratno, \& Sudarti. (2020). The analysis of creative thinking skills of junior high school students in learning natural science on environmental pollution materials with different academic skills. Journal of Physics: Conference Series, 1465, 012032. https://doi.org/10.1088/17426596/1465/1/012032 
Makunja, G. (2016). Challenges Facing Teachers in Implementing Competence-Based Curriculum in Tanzania: The Case of Community Secondary Schools in Morogoro Municipality. International Journal of Education and Social Science, 3(5), 8.

Martin, J. (2020). Job Satisfaction of Professional Librarians and Library Staff. Journal of Library Administration, 60(4), 365-382. https://doi.org/10.1080/01930826.2020.1721941

Merga, M. K. (2019). Do Librarians Feel that Their Profession Is Valued in Contemporary Schools? Journal of the Australian Library and Information Association, 68(1), 18-37. https: //doi.org/10.1080/24750158.2018.1557979

Metz, R. F. (2011). Coaching in the Library: A Management Strategy for Achieving Excellence. ALA Editions. https: //public.ebookcentral.proquest.com/choice/publicfullrecord.aspx?p=678180

Morgan, A. U., D’Alonzo, B. A., Dupuis, R., Whiteman, E. D., Kallem, S., McClintock, A., Fein, J. A., Klusaritz, H., \& Cannuscio, C. C. (2018). Public Library Staff as Community Health Partners: Training Program Design and Evaluation. Health Promotion Practice, 19(3), 361-368. https://doi.org/10.1177/1524839917735304

Mosha, H. J. (2012). A Case Study of Learning Materials Used to Deliver Knowledge and Skills - or Competency-Based Curricula (in Tanzania). Association for the Development of Education in Africa (ADEA), 60.

Oxley, C. (2018). Strength in Numbers: Encouraging Every Staff Member to Work to Capacity. International Information \& Library Review, 50(1), 69-75. https://doi.org/10.1080/10572317.2018.1422907

Rafiq, M., Jabeen, M., \& Arif, M. (2017). Continuing Education (CE) of LIS Professionals: Need Analysis \& Role of LIS Schools. The Journal of Academic Librarianship, 43(1), 25-33. https://doi.org/10.1016/j.acalib.2016.10.004

Raghu, M. M. (2017). Best Library Practices in Business Schools of Hyderabad: A Case Study VJIM. International Journal of Library and Information Studies, Vol.7(4), 12.

Rismita, R., Khuluqo, I. E., Istaryatiningtias, I., \& Hendra, A. N. (2020). The Selection of Outstanding Teachers to the Determination of Ranking on Professional and Intellectual Managerial Performances. Al-Ta Lim Journal, 27(1), 72-79. https://doi.org/10.15548/jt.v27i1.602

Rowley, C., \& Jackson, K. (Eds.). (2011). Human resource management: The key concepts. Routledge.

Solomon, A. O. (2018). Use of Library Resources in Private Secondary Schools in Esan North East Local Government Area, Edo State. Information Impact: Journal of Information and Knowledge Management, 9(2), 30. https://doi.org/10.4314/iijikm.v9i2.3

Suleiman, Y., Hanafi, Z., \& Tanslikhan, M. (2018). Perceived Influence of Library Services on Students' Academic Achievement in Secondary Schools in Kwara State, Nigeria. University of Nebraska Lincoln, 40.

Sunmade, A., \& Anu, A. (2019). Strategies for the Effective Utilisation of the School Library Resources by Junior Secondary Schools in Ilesa West Local Government Education Authority, Ilesa in Osun State, Nigeria. Journal of Library and Information Sciences, $7(2)$. https://doi.org/10.15640/jlis.v7n2a3

Tella, A., \& Ibinaiye, O. A. (2020). Correlates of staff motivation, satisfaction, and job performance of library staff in selected Nigerian University libraries. International Information \& Library Review, 52(1), 32-49. https://doi.org/10.1080/10572317.2019.1631691

Victor, A. A. (2017). Analysis of principals' managerial competencies for effective management of school resources in secondary schools in Anambra State, Nigeria. IJSSHE-International Journal of Social Sciences, Humanities and Education, Volume 1, Number 4, 10.

Zeitoun, S., \& Hajo, Z. (2015). Investigating the Science Process Skills in Cycle 3 National Science Textbooks in Lebanon. American Journal of Educational Research, 3(3), 268-275. https://doi.org/10.12691/education-3-3-3

Zimmerman, R. H., Maker, C. J., \& Alfaiz, F. (2020). Culturally Responsive Assessment of Life Science Skills and Abilities: Development, Field Testing, Implementation, and Results. Journal of Advanced Academics, 31(3), 329-366. https://doi.org/10.1177/1932202X20923981 